\title{
Simultaneous determination of sulfachloropyridazine and trimethoprim in veterinary formulations by hplc
}

\author{
Dönay YUVALI ${ }^{1}$ *(D), Ibrahim NARIN ${ }^{1}$ (iD) \\ ${ }^{1}$ Faculty of Pharmacy, Department of Analytical Chemistry, Erciyes University, 38039, Kayseri Turkey
}

\begin{abstract}
In this study, a simple, sensitive, precise, rapid and reversed-phase high performance liquid chromatographic method with ultraviolet detection for simultaneous determination of Sulfachloropyridazine and Trimethoprim is developed and applied commercial veterinary formulation for chromatographic separation, Thermoscientific Hypersil-C18, reverse phase column was used. Separation was done using acetonitrile: $\mathrm{pH} 3.0$ buffer solution $(30: 70, \mathrm{v} / \mathrm{v})$ at $0.8 \mathrm{ml} \mathrm{min}^{-1}$ flow rate. Analysis was done $272.0 \mathrm{~nm}$ at ultraviyolet detector. Under optimum chromatographic conditions, retention time of Sulfachloropyridazine and Trimethoprim were determined as 4.37 and 2.60 minute. The proposed method was linear in the range 1.0-100.0 $\mu \mathrm{g} \mathrm{ml}^{-1}$ for Sulfachloropyridazine and $0.5-40.0 \mu \mathrm{g} \mathrm{ml}^{-1}$ for Trimethoprim. The Limit of detection of Sulfachloropyridazine and Trimethoprim are $0.05 \mu \mathrm{g} \mathrm{ml}^{-1}, 0.18 \mu \mathrm{g} \mathrm{ml}^{-1}$, respectively. The method which is rapid, simple and does not require any separation step, has been successfully applied to assay of commercial dosage forms containing Sulfachloropyridazine and Trimethoprim.
\end{abstract}

\section{Introduction}

Sulfonamides that called sulfa drugs block folic acid synthesis in bacteria and coccidian by emulating para amino butyric acid. Sulfa drugs were the first chemical substances systematically used to treat and prevent bacterial infections in humans and animals [1]. Sulfachloropyridazine (SCP) is a member of Sulfonamide, effective against many microorganisms. SCP is well tolerated by animals and it is only used for animals. Combination of Sulfa drugs with Trimethoprim (TMP) have a wide spectrum on bacteria and coccidiosis. The using combination of sulfa drugs and TMP have bacteriocidal effect on microorganism $[2,3]$. Antibiotic combinations are frequently used for indications such soft tissue infections, shigellosis, diarrhea, bronchitis for human and animals $[4,5]$.

Several techniques have been presented for determination of SCP and TMP separately or simultaneous with other drugs in veterinary, pharmaceutical or biological samples such as HPLC [6-10], spectrophotometer [11-14], LC/MS/MS [15$18]$, capillary electrophoresis $[19,20]$.

$\mathrm{Ni}$ et al. (2006) applied spectrophometric determination method for sulfonamides by multivariate calibration approaches. Their approches has the aid of chemometrics methods comparing the classical least squares, principal component regression and partial least squares models [21]. This methods requires the application of chemometrics.

Pokaola et al. (2018) presented UV spectrophotometric method for the simultaneous analysis of Sulfadiazine [SDA] and Trimethoprim [TMP] in pharmaceutical formulations. The advantages of Pokaolas method according to analytical purposes that rapid determination, cost-effectiveness and easy preparation. The developed method has not been requirement to chemometrics approches [22]. Abd-Alrassol presented (2017) new spectrophometric determination method for sulfamethoxazole and sulfamerazine in bulk and pharmaceutical dosage forms by a chemical derivatization method involving proton transfer [23]. The spectrophotometric methos have important disadvantages that, matrix effect and analysis time.

Liquid chromatographic methods applies simultaneous separation and minimum matrix effects for drug analysis in different sample matrix. Tahan et al. (2015) developed simultaneous determination method of Sulfamethoxazole (SMZ) and Trimethoprim content in veterinary drugs by HPLC. The diyode array detector was used determination for TMP and SMZ [24]. Goulas et al. (2014) applied HPLC method for the simultaneous determination of sulfadimidine, sulfadiazine, sulfamethoxazole and trimethoprim antibiotics in medicated feeds has been developed 
analysis method to commercial feed premixes after the ultrasound-assisted extraction prosedure [25].

The aim of this study was to investigate simultaneous determination of SCP and TMP combination in veterinary formulations by HPLC. This study described the proposed chromatographic method for simultaneous analysis SCP and TMP in veterinary formulations. The developed method must have be properties such as simple, fast and sensitive for determination and quality control in drug formulation. The time-consuming and pre-treatment procedures weren't prefer to propose a widely applicable routine analysis method.

\section{Materials and Methods}

\subsection{Instruments and reagents}

The chromatographic system is consisted of the commercial components: an Agilent isocratic LC pump, an automatic sample injector system (Agilent 1260 Infinity) and photodiode array detector (Agilent Model G1315D). For chromatographic seperations was used Thermoscientific Hypersil C18 column (150 $\mathrm{mm} \times 4.6 \mathrm{~mm}$ i.d.). SCP and TMP were obtained by Novartis (Ankara, Turkey). HPLC purity methanol, acetonitrile (Merck, Germany) and ortophosphoric acid (Sigma-Aldrich, Germany) were used. Deionized water was provided by using Millipore Elix ${ }^{\circledR} 5$ UV

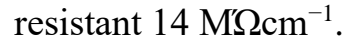

\subsection{Chromatographic analysis}

Chromatographic separation was practiced at room temperature. The SCP and TMP were separated using by mobile phase mix of ACN: $\mathrm{pH} 3.0$ buffer solution (30\% ACN: $70 \%$ pH 3.0 buffer solution). The mobile phase was prepared daily and filtered, sonicated before using. The flow rate for separation was setted as $0.8 \mathrm{ml}$ $\min ^{-1}$ and the chromatogram was monitored at $272 \mathrm{~nm}$. Injection volume of sample and standard was done as $25 \mu 1$.

\subsection{Preparation of standarts and sample solutions}

Standard SCM and TMP solutions were prepared in methanol at concentration of $1 \mathrm{mg} \mathrm{ml}^{-1}$ for calibration curve and sample solutions. The standard solutions were provided by diluated mobile phase at different concentrations range of $1.0-100.0 \mu \mathrm{g} \mathrm{ml}^{-1}$ for SCP and $0.5-40.0 \mu \mathrm{g} \mathrm{ml}^{-1}$ for TMP.

\subsection{Validation of the proposed chromatographic method}

The developed method was validated according to The International Council for Harmonisation of Technical Requirements for Pharmaceuticals for Human Use (ICH) method validation guidelines. The linearity, accuracy, precision, limit of detection (LOD), limit of quantification (LOQ) and robustness were investigated for the validation of developed chromatographic method. Precision was examined interday $(n=6)$, and intradays $(n=5)$. The accuracy and precision of the proposed method were presented by recovery studies and \%RSD, respectively.

\subsection{Application of veterinary formulation}

$1 \mathrm{ml}$ of the oral solution was obtained and diluated to a hundered $\mathrm{ml}$ with HPLC grade methanol. Sample solutions were prepared from diluated oral veterinary formulation. The optimum chromatographic conditions for the HPLC method were applied to determination of SCP and TMP in veterinary formulation. Recovery studies were performed by the standard addition of known amounts of SCP and TMP to a known concentrations of the commercial formulation.

\section{Results and Discussion}

At large quantities mobile phase solvents were prepared and used to provide an optimum chromatographic separation such as methanol, acetonitrile, buffer solutions and deionize water. Mobile phase solvents were examined various mixture and percentage. The mixture of ACN: $\mathrm{pH} 3.0$ buffer solution $(30: 70, \mathrm{v} / \mathrm{v})$ gave better separation and peak symmetry for SCP and TMP. The optimum injection volume was decided to $25 \mu \mathrm{l}$ according to peak symmetry and shape of peak. The retention time for TMP and SCP were found as 2.60, 4.37 min (Fig.1) at optimum chromatographic conditions.

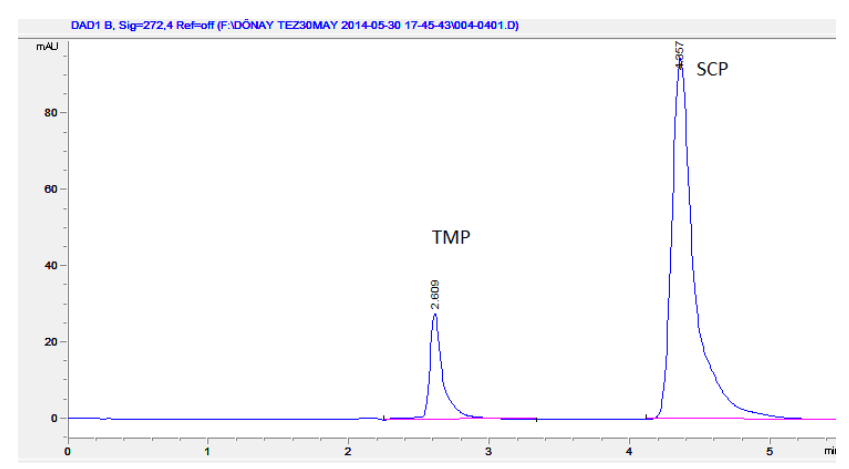

Fig. 1. Chromatogram of simultaneous analysis of SCP and TMP. 


\subsection{The Results of System suitability tests of SCP and TMP for the proposed method}

The system suitability tests are an important part of a liquid chromatographic method. Results of system suitability tests were explained in Table 1. Freshly prepared standard solution of SCP and TMP were used for system suitability tests. The most important system suitability parameter in liquid chromatography is to assure the optimum resolution in the minimum separation time. A resolution value of 1-1.5 or greater between two peaks will provide that the sample components are separated. Resolution of SCP and TMP was found 14.4 in proposed method thus optimum resolution was carried out for sample component.

When capacity factors are very high or very low, the quality of the chromatographic separation is decreased. The capacity factors were obtained as 1.42 for SCP and 0.457 for TMP at optimum separation conditions. All chromatographic peaks would be symmetrical and the peak symmetry ratio is to obtain $\leq 1.5$ for acceptable peak shape. The peak symmetry ration of SCP and TMP are acceptable fort o optimize of HPLC method. The number of theoretical plates $(\mathrm{N})$ is frequently used to correlate the efficiency of a column for a developed method. The number of theoretical plates must to be $\geq$ 2000 for each component according to ICH. The developed method carried out sufficient separation at column by value of N of SCP and TMP. The \% RSD of retention times SCP and TMP have been $0.21 \%$ and $0.14 \%$ and results show a well precision at optimum separation comditions.

Table 1. System suitability parameters of SCP and TMP $(\mathrm{n}=6)$

\begin{tabular}{|c|c|c|}
\hline $\begin{array}{c}\text { System suitability } \\
\text { parameter }\end{array}$ & SCP & TMP \\
\hline Retention time (min) & 4.37 & 2.60 \\
\hline \%RSD of Retention time & 0.23 & 1.54 \\
\hline Resolution & 14.4 & 14.4 \\
\hline Peak symmetry ratio & 0.551 & 0.516 \\
\hline Capacity Factor & 1.42 & 0.457 \\
\hline $\begin{array}{c}\text { The number of theoretical } \\
\text { plate }\end{array}$ & 13191 & 12954 \\
\hline $\begin{array}{c}\text { \% RSD of precision } \\
\text { injection (n=10) }\end{array}$ & 0.09 & 0.39 \\
\hline \multicolumn{2}{|c|}{} \\
\hline
\end{tabular}

\subsection{Analytical performance of the proposed chromatographic method}

By application this method linear dynamic range were observed between the peak area and the concentration of 1.0- $100.0 \mu \mathrm{g} \mathrm{ml}^{-1}$ for SCP and 0.5-40.0 ml-1 for TMP. Table 2 represents calibration characteristic and analytical performance parameters for the proposed method. The LOD and LOQ of the developed method were presented in Table 2, then were calculated $3.0 \mathrm{\sigma} / \mathrm{s}$ and $10 \mathrm{\sigma} / \mathrm{s}$ according to ICH [26]. The precision of the developed method was calculated for interday precision and intraday precision. The interday precision was determined $\leq \% 0.5$ for $\mathrm{SCP}(\mathrm{n}=6)$ and $\leq$ $\% 2.3$ for TMP, intraday precision was determined $\leq$ $\% 1.0$ and $\leq \% 2.5$ respectively.

Table 2. Analytical performance of the developed method

\begin{tabular}{|c|c|c|}
\hline $\begin{array}{c}\text { Validation } \\
\text { parameters }\end{array}$ & SCP & TMP \\
\hline $\begin{array}{c}\text { Linear dynamic } \\
\text { range }\left(\mathrm{mg} \mathrm{ml}^{-1}\right)\end{array}$ & $1.0-100.0$ & $0.5-40.0$ \\
\hline Slope & 113.72 & 30.03 \\
\hline Intercept & 17.18 & 24.51 \\
\hline $\mathrm{r}^{2}$ & 0.9998 & 0.9969 \\
\hline RSD of slope & 1.52 & 1.59 \\
\hline RSD of intercept & 6.20 & 4.43 \\
\hline LOD $\left(\mathrm{mg} \mathrm{ml}^{-1}\right)$ & 0.05 & 0.18 \\
\hline LOQ $\left(\mathrm{mg} \mathrm{ml}^{-1}\right)$ & 0.16 & 0.60 \\
\hline
\end{tabular}

\subsection{The results of application of real sample}

The recoveries study were carried out different concentration levels sample components for the measurement of accuracy of the developed HPLC method. The mean recovery values of developed HPLC method were shown in Table 3 . The recovery values were obtained the range of $99-105 \%$ for SCP and TMP. The accuracy of developed method is acceptable according to analytical parameter.

Table 3. Recovery values of SCP and TMP in veterinary formulation

\begin{tabular}{|c|c|c|c|}
\hline \multicolumn{2}{|c|}{$\begin{array}{c}\text { Added analyte } \\
\text { concentraction } \mu \mathrm{g} \mathrm{ml}^{-1}\end{array}$} & $\frac{\text { Results } \mu \mathrm{g}}{\underline{\mathbf{m l}^{-1}}}$ & $\underline{\text { Mean }}$ \\
\hline \multirow{4}{*}{ SCP } & 0.0 & $27.7 \pm 0.5$ & - \\
\hline & 22.3 & $49.9 \pm 0.4$ & $99.6 \pm 1.8$ \\
\hline & 27.8 & $55.4 \pm 0.7$ & $99.6 \pm 2.6$ \\
\hline & 33.4 & $61.6 \pm 0.1$ & $101.5 \pm 0.2$ \\
\hline \multirow{4}{*}{ TMP } & 0.0 & $5.9 \pm 0.1$ & - \\
\hline & 4.8 & $10.8 \pm 0.1$ & $102.1 \pm 2.4$ \\
\hline & 6.0 & $12.2 \pm 0.1$ & $105.0 \pm 1.1$ \\
\hline & 7.2 & $13.1 \pm 0.1$ & $100.0 \pm 0.7$ \\
\hline
\end{tabular}

The results of analysis of veterinary formulation were presented in Table 4 . The values of result for veterinary formulation are acceptable according to labelled value of drug sample. Therefore the developed method could be use quality control analysis and simultaneous detemination of SCP and TMP. 
Table 4. Result of the determination of SCP and TMP in veterinary dosage form.

\begin{tabular}{|c|c|c|}
\hline Active Compound & $\begin{array}{c}\text { Labelled Claim } \\
(\mathbf{m g})\end{array}$ & $\begin{array}{c}\text { Mean of } \\
\text { amount } \\
\text { found (mg)* }\end{array}$ \\
\hline SCP & 100.0 & $92.2 \pm 1.5$ \\
\hline TMP & 20.0 & $19.5 \pm 0.3$ \\
\hline
\end{tabular}

The proposed chromatographic method was compared other analytical methos in literature at Table 5. The developed HPLC method is first for simultaneous determination of SCP and TMP. The proposed chromatographic method is sufficient accuracy and precision to be analyzied to veterinary formulation.

Table 5. Comparison of the proposed method with other analytical techniques

\begin{tabular}{|l|l|l|c|c|c|}
\hline \multicolumn{1}{|c|}{ Drug molecules } & \multicolumn{1}{|c|}{ Sample } & \multicolumn{1}{|c|}{ İnstrument } & $\begin{array}{c}\text { LOD } \\
(\boldsymbol{\mu g} / \mathbf{m l})\end{array}$ & \% RSD & Ref. \\
\hline $\begin{array}{l}\text { Sulfadiazine, } \\
\text { sulfadimidine, } \\
\text { sulfamethoxazole, } \\
\text { sulfanilamide and } \\
\text { trimethoprim. }\end{array}$ & $\begin{array}{l}\text { Pharmaceutical } \\
\text { and veterinary } \\
\text { formulations }\end{array}$ & $\begin{array}{l}\text { UV/Vis } \\
\text { spectrophotometer } \\
\text { by multivariate } \\
\text { calibration } \\
\text { approaches }\end{array}$ & $\begin{array}{c}240.0- \\
810.0\end{array}$ & $3.1-6.34$ & {$[21]$} \\
\hline $\begin{array}{l}\text { Sulfadiazine and } \\
\text { Trimethoprim }\end{array}$ & $\begin{array}{l}\text { Pharmaceutical } \\
\text { formulations }\end{array}$ & $\begin{array}{l}\text { UV/Vis } \\
\text { spectrophotometer }\end{array}$ & $0.82-0.25$ & $2.3-2.1$ & {$[22]$} \\
\hline $\begin{array}{l}\text { Sulfamethoxazole } \\
\text { and sulfamerazine } \\
\text { pharmaceutical } \\
\text { dosage }\end{array}$ & $\begin{array}{l}\text { Bulk } \\
\text { spectrophotometer }\end{array}$ & 670.0 & $1.6-1.5$ & {$[23]$} \\
\hline $\begin{array}{l}\text { sulfamethoxazole } \\
\text { and trimethoprim }\end{array}$ & $\begin{array}{l}\text { Veterinary } \\
\text { medicines }\end{array}$ & HPLC-DAD & ---- & $0.99-2.7$ & {$[24]$} \\
\hline $\begin{array}{l}\text { sulphadimidine, } \\
\text { sulphadiazine, } \\
\text { sulphamethoxazol } \\
\text { e } \\
\text { trimethoprim and }\end{array}$ & feed premixes & HPLC-UV & --- & $1.3-4.16$ & {$[25]$} \\
\hline $\begin{array}{l}\text { Sulfachloroprydaz } \\
\text { ine } \\
\text { trimethoprim and }\end{array}$ & $\begin{array}{l}\text { Veterinary } \\
\text { formulation }\end{array}$ & HPLC-UV & $0.05-0.18$ & $1.0-2.5$ & $\begin{array}{c}\text { This } \\
\text { work }\end{array}$ \\
\hline
\end{tabular}

\section{Conclusions}

The developed HPLC method is simple, fast, reliable and validated for simultaneous determination of SCP and TMP at first time. This method has a well resolution between SCP and TMP moreover the analysis time is very short. The proposed chromatographic methods accuracy, precision and the kimit of detection values are particularly satisfactory and comparable with more other analytic protocols. Thus developed method could be suggested for quality control analysis of and determination of veterinary formulation which are containing SCP and TMP.

\section{Acknowledgment}

This work was studied at Erciyes University Faculty of Pharmacy Research Laboratories.

\section{Conflicts of interest}

The authors state that did not have conflict of interests.

\section{References}

[1] Plumb D.C, Veterinary Drug Handbook (3rd ed.), Iowa State University Press, Ames, (1999) 584-587.

[2] Kanbur M., Liman C., Eraslan G., et al. Effects of Various Cooking and Freezing Processes on the Residues of SulfachlorpyridazineTrimethoprim Combination in Broiler Tissues. Kafkas Univ. Vet Fak Derg , 20 (4) (2010) 487492.

[3] Agrawal K. V., Analysis of Antibiotic/Drug Residues in Food Products of Animal origin, 
(1st ed), Plenum Press, New York, (1991) 11140.

[4] Hess M. M., Boucher B.A., Laizure S. C., et al. Trimethoprim-sulfamethoxazole

pharmacokinetics in trauma patients. Pharmacotherapy. 13(6) (1993) 602-606.

[5] Stephen H., Kenneth H., in Mandell, Douglas, and Bennett's Principles and Practice of Infectious Diseases (Eighth Edition), Elsevier Inc. (2015).

[6] Zhang W., Duan C., Wang M., Analysis of seven sulphonamides in milk by cloud point extraction and high performance liquid chromatography. Food Chemistry, 126 (2011) 779-785.

[7] Blackwell A.P, Holten Lützhøft C.H, Mab P.H. et al. Fast and robust simultaneous determination of three veterinary antibiotics in groundwater and surface water using a tandem solid-phase extraction with high-performance liquid chromatography-UV detection. $J$ Chromatography A, 1045 (2004) 111-117.

[8] Kristof E. M, Zhang G.F, Lambert W.E. Quantitative analysis of twelve sulfonamides in honey after acidic hydrolysis by highperformance liquid chromatography with postcolumn derivatization and fluorescence detection. J Chromatography A, 1047 (2004) 85-92.

[9] Amini H., Ahmadiani A., Rapid and simultaneous determination of sulfamethoxazole and trimethoprim in human plasma by high-performance liquid chromatography. $J$ Pharmaceutical and Biomedical Analysis, 43 (2007) 1146-1150.

[10] Pereira A.V, Cass Q.B, High-performance liquid chromatography method for the simultaneous determination of sulfamethoxazole and trimethoprim in bovine milk using an on-line clean-up column. $J$ Chromatography B, 826 (2005) 139-146.

[11] Kanbur M., Narin İ., Özdemir E., Fractional Wavelet Transform for the Quantitative Spectral Analysis of Two-Component System. Fractional Modelling, In: New Trends in Nanotechnology and Fractional Calculus Applications, Baleanu D., Güvenç Z.B., Machado T.J.A., Springer Dordrecht Heidelberg, London, New York, (2010) 321-331.

[12] Granero G., Garnero C., Longhi M., Second derivative spectrophotometric determination of trimethoprime and sulfamethoxazole in the presence of hydroxypropyl- $\beta$-cyclodextrin. $J$ Pharmaceutical and Biomedical Analysis, 29 (2002) 51-59.
[13] Gallego J. M, Arroyo J., Spectrophotometric resolution of ternary mixtures of Dexamethasone, Polymyxin B and Trimethoprim in synthetic and pharmaceutical formulations. Analytica Chimica Acta, 437 (2001) 247-257.

[14] López-Martínez L., López-de-Alba P.L., deLeón-Rodríguez L.M., Yepez-Murrieta M.L., Simultaneous determination of binary mixtures of trimethoprim and sulfamethoxazole or sulphamethoxypyridazine by the bivariate calibration spectrophotometric method. Journal of Pharmaceutical and Biomedical Analysis 30(1) (2002) 77-85.

[15] Le-Minh N., Stuetz M. R., Khan S.J., Determination of six sulfonamide antibiotics, two metabolites and trimethoprim in wastewater by isotope dilution liquid chromatography/tandem mass spectrometry, Talanta 89 (2012) 407- 416.

[16] Economou A., Petraki O., Tsipi D., Botitsi E.. A liquid chromatography-tandem mass spectrometry method for the determination of sulfonamides, trimethoprim and dapsone in honey and validation according to Commission Decision 2002/657/EC for banned compounds. Talanta, 97 (2002) 32-41.

[17] Solliec M., Masse D., Sauve S., Analysis of trimethoprim, lincomycin, sulfadoxin and tylosin in swine manure using laser diode thermal desorption-atmospheric pressure chemical ionization-tandem mass spectrometry. Talanta, 128 (2014) 23-30.

[18] Forti A.F, Scortichini G., Determination of ten sulphonamides in egg by liquid chromatography-tandem mass spectrometry, Analytica Chimica Acta 637 (2009) 214-219.

[19] Lara F.J, García-Campa na M.A, Neusüss C., Alés-Barrero F., Determination of sulfonamide residues in water samples by in-line solid-phase extraction-capillary electrophoresis, $J$ of Chromatography A, 1216 (2009) 3372-3379.

[20] da Silva I.S., Vidal D.T., do Lago C.L., Angnes L., Fast simultaneous determination of trimethoprim and sulfamethoxazole by capillary zone electrophoresis with capacitively coupled contactless conductivity detection. J Sep Sci. 36(8) (2013) 1405-1409.

[21] Ni Y., Qi Z., Kokot S., Simultaneous ultraviolet-spectrophotometric determination of sulfonamides by multivariate calibration approaches. Chemometrics and Intelligent Laboratory Systems. 82 (1-2) (2006) 241-247.

[22] Pokala R. V., Kusuma Kumari K., Bollikola H. B., UV spectrophotometry method development 
and validation of sulfadiazine and trimethoprim in combined dosage form. Int J Pharm Pharm Sci. 10(1) (2018) 103-107.

[23] Abd-Alrassol K.S., Spectrophotometric method for the determination of sulfa drug in pharmaceuticals based on charge transfer reaction. J. of Chemical and Pharmaceutical Research. 9(2) (2017) 244-251.

[24] Tahan G. P., Machado S.C., Malaguti E. C., Maia P.P., Susanne Rath S., Martins I., RP-LC method for simultaneous determination ofsulfamethoxazole and trimethoprim content in veterinary drugs . Eclética Química. 40 (2015) $32-41$.
[25] Goulas V., Anisimova Andreou T., Angastinioti Moditi C., Tzamaloukas O., A rapid HPLC method for the determination of sulphonamides and trimethoprim in feed premixes. Journal of Animal and Feed Science. 23 (2014) 185-189.

[26] The European Agency for the evaluation of Medicinal Products. ICH Topic Q2B Notefor Guideline on Validation of Analytical procedures: Methodology GPMP/ICH/281/95, 1996 Retrieved from; https://www.ema.europa.eu/en/documents/scien tific-guideline/ich-q-2-r1-validation-analyticalprocedures-text-methodology-step-5_en.pdf. 